\title{
Predictors of long length of hospital stay among elders admitted with seizures in a tertiary centre: a prospective study
}

\author{
Preditores de longo tempo de internação hospitalar entre idosos admitidos com \\ crises epilépticas em um centro terciário: um estudo prospectivo
}

Aroldo BACELLAR', Telma Rocha de ASSIS', Bruno Bacellar PEDREIRA', Luan CÔRTES², Silas SANTANA², Osvaldo José Moreira do NASCIMENTO3

\begin{abstract}
Population ageing is a global phenomenon, and life expectancy in Brazil is growing fast. Epilepsy is the third most important chronic neurological disorder, and its incidence is higher among elderly patients than in any other segment of the population. The prevalence of epilepsy is greater among inpatients than in the general population and it is related to long length of hospital stay (LOS), which is associated with hospital mortality and higher healthcare costs. Despite these facts, reports of elderly inpatients admitted with seizures and associated outcomes are scarce. Objective: To identify predictors of long LOS among elderly inpatients admitted with seizures. Methods: We prospectively enrolled elders admitted with epileptic seizures or who experienced seizures throughout hospitalization between November 2015 and August 2019. We analysed demographic data, neurological disorders, clinical comorbidities, and seizure features to identify risk factors. Results: The median LOS was 11 days, with an interquartile range (IQR) of 5-21 days. The frequency of long LOS (defined as a period of hospitalization $\geq 12$ days) was $47 \%$. Multivariate analysis showed there was an exponential increase in long LOS if a patient showed any of the following conditions: intensive care unit (ICU) admission (OR=4.562), urinary tract infection (OR=3.402), movement disorder (OR=5.656), early seizure recurrence $(\mathrm{OR}=2.090)$, and sepsis $(\mathrm{OR}=4.014)$. Conclusion: Long LOS was common among elderly patients admitted with seizures, and most predictors of long LOS found in this cohort might be avoidable; these findings should be confirmed with further research.
\end{abstract}

Keywords: Epilepsy; Seizure; Aged; Length of Stay; Risk Factors.

\section{RESUMO}

O envelhecimento populacional é um fenômeno global e o crescimento da expectativa de vida no Brasil tem sido rápido. A epilepsia é a terceira doença neurológica crônica mais importante e sua incidência em idosos é maior do que em qualquer outro segmento populacional. A prevalência de epilepsia é maior entre pacientes internados e está relacionada a longo tempo de internação (TDI), o qual está associado a custos elevados e mortalidade hospitalar. Apesar disso, são escassos os relatos de desfechos de pacientes idosos internados com crises epilépticas e resultados associados. Objetivo: Identificar fatores de risco de longo TDI em idosos admitidos com crises epilépticas. Métodos: Recrutamos prospectivamente pacientes idosos admitidos com crises epilépticas ou que tiveram crises durante a internação hospitalar entre novembro de 2015 e agosto de 2019. Analisamos dados demográficos, distúrbios neurológicos, comorbidades clínicas e tipos de crise epiléptica para identificar fatores de risco. Resultados: A mediana do TDI foi 11 dias, com intervalo interquartil (IIQ) de 5-21 dias. A frequência de longo TDI (definido como TDI $\geq 12$ dias) foi 47\%. A análise multivariada mostrou que houve um aumento exponencial de TDI quando o paciente apresentou algumas dessas condições: admissão em unidade de terapia intensiva (UTI) (OR=4,562), infecção urinária $(\mathrm{OR}=3,402)$, transtorno do movimento $(\mathrm{OR}=4,562)$, recorrência precoce de crise epiléptica $(\mathrm{OR}=2,090)$ e sepse $(\mathrm{OR}=4,014)$. Conclusão: Longo TDI é um desfecho desfavorável importante e foi comum entre idosos admitidos com crises epilépticas. Muitos dos preditores de longo TDI encontrados nessa coorte podem ser evitados, o que deve ser confirmado com pesquisas futuras.

Palavras-chave: Epilepsia; Convulsões; Idoso; Tempo de Internação; Fatores de Risco.

\footnotetext{
'Hospital São Rafael, Department of Neurology, D'Or Institute for Research and Education, Salvador BA, Brazil.

${ }^{2}$ Resident of the Department of Neurology, Hospital São Rafael, Monte Tabor Foundation, Italian-Brazilian Centre for Health Promotion, Salvador BA, Brazil. ${ }^{3}$ Universidade Federal Fluminense, Department of Neurology, Rio de Janeiro RJ, Brazil.

Aroldo BACELLAR (D) https://orcid.org/0000-0001-8452-0932; Telma Rocha de ASSIS (D) https://orcid.org/0000-0002-9943-3396; Bruno Bacellar PEDREIRA (DD https://orcid.org/0000-0003-4100-0974; Luan CÔRTES (ID https://orcid.org/0000-0001-8465-1289;

Silas SANTANA (iD) https://orcid.org/0000-0001-8291-8445; Osvaldo José Moreira do NASCIMENTO (iD https://orcid.org/0000-0003-3516-485X

Correspondence: Aroldo Bacellar; email: aroldo.bacellar@gmail.com

Conflict of interest: There is no conflict of interest to declare.

Authors' contributions: AB conceived the study idea, designed the methods, collected data, performed statistical analysis, and drafted the manuscript; TA, BBP, LC, and SS collected data, examined medical records, and reviewed manuscript drafts; LC also performed the English editing; OJN discussed the study idea, methods, statistical analysis, and results. All authors read, discussed, and approved the final manuscript.

Data availability: The data used to support the findings of this study are available from the corresponding author upon request.

Received on January 9, 2020; Received in its final form on April 17, 2020; Accepted on May 27, 2020.
}

(cc) BY 
Population ageing is a worldwide phenomenon and it will become the most significant social transformation of the twenty-first century ${ }^{1}$. In Brazil, the population of individuals aged $\geq 60$ years surpassed 30 million in 2017, and life expectancy in this country is growing faster than in developed nations ${ }^{2}$. Epilepsy is a common chronic neurological disorder, second only to cerebrovascular disease and dementia, and its incidence is higher in the elderly than in any other age group ${ }^{3}$. Long LOS is common among patients with epilepsy, particularly in the elderly who experience early seizure recurrence and who suffer from status epilepticus (SE), and it is associated with hospital mortality and excessive healthcare spending ${ }^{4,5,6,7}$. Although especially common in the elderly, long LOS can be prevented ${ }^{8}$. Studies of neurological disorders among elders admitted to a tertiary centre in Salvador found epilepsy in $16 \%$ of elderly inpatients, and the majority of them had a long $\operatorname{LOS}^{9,10}$. Notwithstanding these facts, reports of elderly inpatients admitted with epileptic seizures in Brazil are scarce $e^{7,11,12,13,14,15,16}$. The aim of the present study was to identify independent predictors of long LOS in a cohort of elderly inpatients who were admitted with epileptic seizures or experienced seizures during hospitalization.

\section{METHODS}

\section{Participants}

This prospective, observational, single-centre study included patients aged $\geq 60$ years who were consecutively admitted to Hospital São Rafael, a general tertiary teaching hospital with 356 beds in Salvador, Brazil, between 1 November 2015 and 31 August 2019.

\section{Inclusion criteria}

We enrolled elderly inpatients with seizures that either led to their hospital admission or occurred in a period of care in the emergency department, or throughout hospitalization. Overall, patients were under the care of a neurology team.

\section{Exclusion criteria}

Elderly inpatients excluded from the study were: (1) those who had been admitted with a diagnosis of seizure that was not confirmed or who were later diagnosed with other paroxysmal neurological disorders such as syncope, delirium, or transient ischaemic attack; and (2) those who had seizures in the setting of acute traumatic brain injury (TBI) and were followed up by the neurosurgery team.

\section{Demographics}

We studied patient age and sex, age at the first seizure, marital status, admission to the intensive care unit, and discharge conditions, and their relationship with long LOS.

\section{Neurological disorders and clinical comorbidities}

We investigated the most common neurological disorders and comorbidities that are related to epileptic seizures among elderly inpatients. These disorders were classified according to the Tenth Revision of the International Statistical Classification of Diseases ${ }^{17}$. Dementia, delirium, and psychiatric disorders were diagnosed according to the DSM-5 $5^{18,19}$.

\section{Neurological disorders}

We analysed the frequency of long LOS among neurological disorders which have been associated with epileptic seizures and might prolong hospitalization: epilepsy, cerebrovascular disease, ischaemic stroke, sequelae of stroke, brain haemorrhage, movement disorder, Parkinson's disease, dementia, Alzheimer's disease, vascular dementia, delirium, neurotoxic and metabolic encephalopathy, brain tumours, central nervous system (CNS) infection, brain injury, headache, CNS autoimmune disorders, and neuromuscular disorders.

\section{Clinical comorbidities}

Hypertension, diabetes mellitus, dyslipidaemia, cardiac arrhythmia, atrial fibrillation, myocardial infarction, congestive heart failure, kidney disease, gastrointestinal disorders, liver disease, endocrine and metabolic disorders, hypothyroidism, blood and haematopoietic disorders, acute respiratory disorder, chronic respiratory disorder, non-brain tumours, psychiatric disorder, lung infection, and urinary tract infection, as well as sepsis were investigated as predictors of long LOS in the study population.

\section{Epilepsy and seizure disorders}

We adopted the International League Against Epilepsy (ILAE) classification of epilepsy ${ }^{20}$. It presents three levels, starting with seizure type, assuming that the patient is having an epileptic seizure as defined by the '2017 ILAE Operational Classification of Seizure Types ${ }^{21}$.

\section{Seizure characteristics and diagnosis}

The clinical characteristics of seizures were described according to the latest recommendations, based on the Operational Classification of Seizure Types by the ILAE ${ }^{21}$. An acute symptomatic seizure or provoked seizure was diagnosed as 'a clinical seizure occurring at the time of a systemic insult or in close temporal association with a documented brain insult ${ }^{22}$. Brain insult, according to the commission, was specified as 'events occurring within one week of stroke, TBI, anoxic encephalopathy, or intracranial surgery, at first identification of subdural hematoma, at the presence of an active CNS infection, or during an active phase of multiple sclerosis or other autoimmune diseases'. Seizures occurring within 24 hours of severe metabolic derangements, drug or alcohol intoxication and 
withdrawal, or exposure to proconvulsant drugs were also considered acute symptomatic seizures ${ }^{22}$.

To define an acute symptomatic (provoked) seizure resulting from metabolic imbalance, we used the following cut-off values, which are most likely to be associated with seizures: sodium: $<115 \mathrm{mg} / \mathrm{dL}$ (or $>145 \mathrm{mmol} / \mathrm{L}$ ), calcium: $<5.0 \mathrm{mg} / \mathrm{dL}$, magnesium: $<0.8 \mathrm{mg} / \mathrm{dL}$, serum glucose: $<36 \mathrm{mg} / \mathrm{dL}$ (or $>450 \mathrm{mg} / \mathrm{dL}$ when associated with ketoacidosis), blood urea: $>214 \mathrm{mg} / \mathrm{dL}$, and creatinine: $>10 \mathrm{mg} / \mathrm{dL}^{22}$.

Seizure aetiology was categorized as (1) symptomatic (known cause), including a) acute seizures (e.g. stroke, CNS infection, metabolic disorder, and autoimmune disease), b) remote seizures (e.g. post stroke, posttraumatic, and postencephalitic), and c) progressive symptomatic (brain tumour and dementia); and as (2) unknown cause ${ }^{23,24}$. An unprovoked seizure was defined as a seizure occurring in the absence of a temporary or reversible provocative factor ${ }^{25}$. First unprovoked seizure might be considered epilepsy in special situations or in cases of relapse, according to the ILAE ${ }^{25}$. Early recurrent seizure was defined as a second seizure event, unprovoked and separated from the first seizure by more than 24 hours up to the 30th day after the index seizure.

\section{Epilepsy}

After diagnosing the seizure type, the next step was the diagnosis of the type of epilepsy according to the recommendations of the ILAE Official Report ${ }^{25}$. The diagnosis of SE included the revised concepts, definition, and classification from the report of the ILAE Task Force on Classification of Status Epilepticus ${ }^{24}$.

Patient multimorbidity was defined as the coexistence of two or more chronic conditions ${ }^{26}$. Investigation of seizure aetiology included laboratory tests (glucose, urea, magnesium, sodium, calcium, and creatinine), routine electroencephalogram (EEG), 24-hour video-EEG, and brain imaging data (computed tomography, magnetic resonance imaging [MRI], MRI angiography, and positron emission tomography). Some patients also underwent cerebrospinal fluid analysis. The following EEG results were considered abnormal: diffuse or focal slowing abnormalities and interictal or ictal paroxysms. This definition excluded records with nonspecific abnormalities.

Epilepsy, SE (convulsive and non-convulsive SE), acute symptomatic seizure (provoked), seizure types (focal onset, generalized onset, unknown onset), and epilepsy aetiology (structural, metabolic, immune, infectious, genetic, and unknown) were studied as independent predictors of long LOS.

\section{Long length of stay}

Long LOS was defined as a patient stay of 12 days or longer, since the median LOS in this population was 11 days.

\section{Statistics}

Quantitative variables with normal distribution were reported as means and standard deviations, whereas variables with non-normal distribution were expressed as medians and interquartile intervals. Normal variables were identified by graphic analysis and the Shapiro-Wilk test. Categorical variables were reported as frequencies and percentages. Student's t-test was used to perform bivariate comparisons between groups for numerical variables with normal distribution. Categorical variables were compared by Pearson's chi-square or Fisher's exact test when necessary. We performed a stepwise hierarchical logistic regression for multivariate analysis to increase the predictive power of the model. Independent variables were considered for multivariate analysis if recognized as having biological plausibility regarding the main study hypotheses and when bivariate tests showed a $p<0.25$, in accordance with the algorithm proposed by Hosmer and Lemeshow. Nagelkerke R2, the Hosmer-Lemeshow test, Cox and Snell R2 (ML), and the likelihood-ratio test were employed to measure the dimension of the model. A receiver operating characteristic (ROC) curve was obtained to assess the discriminant capacity of the model.

Statistical Package for the Social Sciences (SPSS) (v. 25, Chicago, IL), R Program (v. 3.4.4), and Microsoft Excel ${ }^{\circledast} 2016$ were used to perform statistical analyses.

\section{Ethics}

This study was approved by the Research Ethics Committee of Hospital São Rafael on 24 November 2014 under the protocol number 904.379, version 5 (CAAE 37689414.6.0000.0048).

\section{RESULTS}

\section{Demographics and neurological disorders}

This study enrolled 159 inpatients aged $\geq 60$ years who met our eligibility criteria; however, one patient was excluded from the analysis of long LOS as he was still in the hospital at the end of enrolment. The mean age of patients was $76.67 \pm 9.98$ and the median was 77 years (IQR: 68-85 years). Mean age at first seizure was $75.4 \pm 11.6$, with a median of 76 years (IQR: 67-85 years). Males were $51.6 \%$ of the study population, and $61 \%$ of patients were married. The median length of stay was 11 days, with an IQR of 5-21 days and a mean of 17.7 \pm 15.1 days. Long LOS occurred in 74 (47\%) patients and hospital mortality in 14 (9\%).

As expected, epilepsy was the most common neurological disorder among this elderly population who were admitted with epileptic seizures or who experienced seizures during hospitalization (127 [80\%] patients). Epilepsy was followed in frequency by cerebrovascular disease and dementia. Table 1 shows associations of demographic data and neurological disorders with LOS.

\section{Clinical comorbidities}

Hypertension was the most frequent clinical comorbidity, followed by diabetes mellitus. Table 2 shows associations between clinical comorbidities and long LOS. 
Table 1. Univariate analysis of demographics and neurological disorders in relation to the occurrence of long length of stay in 158 elderly inpatients admitted with seizures or who experienced seizures throughout hospitalization in a tertiary medical centre.

\begin{tabular}{|c|c|c|c|}
\hline & & _ong LOS & \\
\hline & $\begin{array}{c}\text { No } \\
n(\%)\end{array}$ & $\begin{array}{l}\text { Yes } \\
\text { n (\%) }\end{array}$ & $p$-value \\
\hline Female & $35(41.7)$ & $42(56.8)$ & 0.058 \\
\hline Age, years & $74.8(10.1)$ & $79.0(9.2)$ & 0.007 \\
\hline Mean age at first seizure & $73.9(12.4)$ & $78.3(9.9)$ & 0.003 \\
\hline Discharged home & $78(94)$ & $49(67.1)$ & $<0.001$ \\
\hline Married & $50(59.5)$ & $46(62.2)$ & 0.673 \\
\hline ICU admission & $35(41.7)$ & $61(82.4)$ & $<0.001$ \\
\hline $\begin{array}{l}\text { Median number of } \\
\text { comorbidities }\end{array}$ & $5(3-6)$ & $6(4-7)$ & 0.022 \\
\hline Epilepsy & $69(82.1)$ & $57(77)$ & 0.425 \\
\hline Cerebrovascular disease & $43(51.2)$ & $44(59.5)$ & 0.297 \\
\hline Ischaemic stroke & $38(45.2)$ & $43(58.1)$ & 0.106 \\
\hline Brain haemorrhage & $6(7.1)$ & $3(4.1)$ & 0.503 \\
\hline Sequelae of previous stroke & $22(26.2)$ & $27(36.5)$ & 0.163 \\
\hline Dementia & $23(27.4)$ & $21(28.4)$ & 0.889 \\
\hline Alzheimer's disease & $9(10.7)$ & $8(10.8)$ & 0.984 \\
\hline Vascular dementia & $1(1.2)$ & $3(4.1)$ & 0.341 \\
\hline Delirium & $8(9.5)$ & $14(18.9)$ & 0.089 \\
\hline Neurotoxic and metabolic & $4(4.8)$ & 11(15.1) & 0.028 \\
\hline Movement disorder & $3(3.6)$ & $11(14.9)$ & 0.022 \\
\hline Parkinson's disease & $0(0)$ & $6(8.1)$ & 0.009 \\
\hline Brain tumour & $4(4.8)$ & $5(6.8)$ & 0.735 \\
\hline Neuromuscular disorders & $4(4.8)$ & $6(8.1)$ & 0.517 \\
\hline CNS infection & $0(0)$ & $5(6.8)$ & 0.21 \\
\hline Brain injury & $1(1.2)$ & $5(6.8)$ & 0.999 \\
\hline Headache & $2(2.4)$ & $2(2.7)$ & 0.999 \\
\hline
\end{tabular}

Data are expressed as number of patients, with percentages (\%), standard deviation (for age), or interquartile range (median number of comorbidities) in brackets; LOS: length of stay.

\section{Seizure characteristics and epilepsy}

Focal onset seizures were the most common clinical presentation in this study population, and we found a higher frequency of structural causes in patients diagnosed with epilepsy. Table 3 shows the univariate analysis of seizure disorders and epilepsy in relation to the occurrence of long LOS.

\section{Univariate analysis}

Female sex, ageing, mean age at first seizure, discharge home, admission to the ICU, number of comorbidities (patient multimorbidity), ischaemic stroke, sequelae of previous stroke, delirium, neurotoxic and metabolic disorders, movement disorder, Parkinson's disease, CNS infection, urinary tract infection, endocrine and metabolic disorders, cardiac arrhythmia, atrial fibrillation, kidney disease, sepsis, lung infection, congestive heart failure, acute respiratory
Table 2. Univariate analysis of comorbidities in relation to long length of stay in 158 elderly patients admitted with seizures or who experienced seizures throughout hospitalization in a tertiary medical centre.

\begin{tabular}{|c|c|c|c|}
\hline & \multicolumn{3}{|c|}{ Long LOS } \\
\hline & $\begin{array}{l}\text { No } \\
n(\%)\end{array}$ & $\begin{array}{l}\text { Yes } \\
\mathrm{n}(\%)\end{array}$ & $p$-value \\
\hline Hypertension & $68(81)$ & $62(83.8)$ & 0.642 \\
\hline Diabetes mellitus & $32(38.1)$ & $34(45.9)$ & 0.318 \\
\hline Dyslipidaemia & $47(56)$ & $36(48.6)$ & 0.359 \\
\hline Psychiatric disorder & $28(33.3)$ & $28(37.8)$ & 0.555 \\
\hline Urinary tract infection & $14(16.7)$ & $31(41.9)$ & $<0.001$ \\
\hline $\begin{array}{l}\text { Endocrine and metabolic } \\
\text { disorders }\end{array}$ & $19(22.6)$ & $25(33.8)$ & 0.118 \\
\hline Cardiac arrhythmias & $16(19)$ & $24(32.4)$ & 0.054 \\
\hline Atrial fibrillation & $12(14.3)$ & $18(24.3)$ & 0.108 \\
\hline Kidney disease & $13(15.5)$ & $22(29.7)$ & 0.031 \\
\hline $\begin{array}{l}\text { Blood and haematopoietic } \\
\text { disorders }\end{array}$ & $12(14.3)$ & $10(13.5)$ & 0.889 \\
\hline Non-brain tumours & $15(17.9)$ & $15(20.3)$ & 0.700 \\
\hline Hypothyroidism & $18(21.4)$ & $10(13.5)$ & 0.194 \\
\hline Sepsis & $3(3.6)$ & $22(29.7)$ & $<0.001$ \\
\hline Lung infection & $6(7.1)$ & $15(20.3)$ & 0.015 \\
\hline Myocardial infarction & $9(10.7)$ & $8(10.8)$ & 0.984 \\
\hline Congestive heart failure & $4(4.8)$ & $10(13.5)$ & 0.053 \\
\hline Liver disease & $8(9.5)$ & $4(5.4)$ & 0.330 \\
\hline Chronic respiratory disease & $4(4.8)$ & $6(8.1)$ & 0.517 \\
\hline Acute respiratory disorder & $0(0)$ & $8(10.8)$ & 0.002 \\
\hline Sequelae of previous stroke & $22(26.2)$ & $27(36.5)$ & 0.163 \\
\hline
\end{tabular}

Data are expressed as number of patients, with percentages (\%) in brackets; LOS: length of stay.

disorder, early seizure recurrence, SE (convulsive and nonconvulsive), acute symptomatic seizure, unknown aetiology of seizure, and unknown aetiology of epilepsy were associated with length of stay according to the inclusion criteria for multivariate analysis (Tables 1,2, and 3).

\section{Multivariate analysis}

Table 4 shows the results of the logistic regression on the aggregate variables hypothesized as predictors of long LOS, some of which had a statistically significant effect on the logit probability of long LOS.

Statistics for the evaluation of the model dimension effect proved to be adequate in the final adjustment as follows: pseudo-R2, Cox and Snell R2 (R2 CS=0.333), Nagelkerke R2 (R2N=0.421), Hosmer-Lemeshow test $\left(\chi^{2} \mathrm{HL}(8)=10.616\right.$; $\mathrm{p}=0.224)$, and likelihood-ratio test $(\mathrm{G} 2(7)=153.67 ; \mathrm{p}<0.001)$.

The model yielded a sensitivity of $74.3 \%$ and a specificity of $81.9 \%$, resulting in an accuracy of $76.6 \%$, as shown in the ROC curve (Figure 1).

We found an exponential increase in the occurrence oflong LOS when the patient showed any of these conditions: ICU 
Table 3. Univariate analysis of seizure disorders in relation to long length of stay in 158 elderly patients admitted to a tertiary medical centre.

\begin{tabular}{|c|c|c|c|}
\hline \multirow[b]{2}{*}{ Seizure disorders } & \multicolumn{3}{|c|}{ Long LOS } \\
\hline & $\begin{array}{c}\text { No } \\
\text { n (\%) }\end{array}$ & $\begin{array}{c}\text { Yes } \\
\text { n (\%) }\end{array}$ & $p$-value \\
\hline \multicolumn{4}{|l|}{ Seizure type } \\
\hline Focal onset & $54(64.3)$ & $46(62.2)$ & 0.782 \\
\hline Generalized onset & $24(28.6)$ & $26(35.1)$ & 0.376 \\
\hline Unknown type & $7(8.3)$ & $3(4.1)$ & 0.338 \\
\hline \multicolumn{4}{|l|}{ Seizure disorders } \\
\hline Seizure early recurrence & $15(18.1)$ & $29(39.2)$ & 0.003 \\
\hline SE & $19(22.6)$ & $30(40.5)$ & 0.015 \\
\hline Convulsive SE & $16(19)$ & $21(28.4)$ & 0.167 \\
\hline Non-convulsive SE & $6(7.1)$ & $10(13.5)$ & 0.185 \\
\hline \multicolumn{4}{|l|}{ Seizure aetiology } \\
\hline Symptomatic remote & $22(26.2$ & $14(18.9)$ & 0.277 \\
\hline Symptomatic acute seizure & $12(14.3)$ & $17(23)$ & 0.159 \\
\hline Symptomatic progressive & $13(15.5)$ & $16(21.6)$ & 0.319 \\
\hline Unknown aetiology & $20(23.8)$ & $4(5.4)$ & 0.001 \\
\hline \multicolumn{4}{|l|}{ Aetiology of epilepsy } \\
\hline Structural & $52(61.9)$ & $49(66.2)$ & 0.475 \\
\hline Unknown & $12(14.3)$ & $3(4.1)$ & 0.090 \\
\hline Infectious & $1(1.2)$ & $4(5.4)$ & 0.291 \\
\hline Immune & $1(1.2)$ & $1(1.4)$ & 0.958 \\
\hline Metabolic & $0(0)$ & $0(0)$ & 0.786 \\
\hline Genetic & $0(0)$ & $0(0)$ & 0.786 \\
\hline
\end{tabular}

Data are expressed as number of patients, with percentages (\%) in brackets; LOS: length of stay; SE: status epilepticus. admission (356.2\%), urinary tract infection (240.2\%), movement disorder (465.6\%), early seizure recurrence (109.0\%), and sepsis (301.4\%). However, there was a low chance of long LOS for patients with unknown aetiology of seizure $(74.8 \%)$, female sex (45.8\%), and hypothyroidism (65.0\%).

The residual analysis plot for detecting influential cases showed only 7 cases (4.4\%) in the dataset were potential outliers, since they had high values of standard residuals and were therefore incorrectly classified by the logistic model (Figure 2). However, they were kept in the final model, as

Table 4. Aggregate variables with a statistically significant effect $(p<0.25)$ on the logit probability of long length of stay among 158 elderly patients admitted with seizures or who experienced seizures throughout hospitalization in a tertiary medical centre.

\begin{tabular}{|c|c|c|c|c|}
\hline Variable & $\begin{array}{l}\text { Estimated } \\
\text { coefficients }\end{array}$ & $\begin{array}{c}\text { Wald } \\
\text { chi-square }\end{array}$ & $p$-value & OR \\
\hline Female sex & -0.610 & 2.211 & 0.137 & 0.543 \\
\hline ICU admission & 1.518 & 11.777 & 0.001 & 4.562 \\
\hline $\begin{array}{l}\text { Movement } \\
\text { disorder }\end{array}$ & 1.733 & 4.502 & 0.034 & 5.656 \\
\hline $\begin{array}{l}\text { Urinary tract } \\
\text { infection }\end{array}$ & 1.224 & 6.969 & 0.008 & 3.402 \\
\hline Hypothyroidism & 1.050 & 3.462 & 0.063 & 0.350 \\
\hline Sepsis & 1.390 & 3.813 & 0.051 & 4.014 \\
\hline $\begin{array}{l}\text { Early seizure } \\
\text { recurrence }\end{array}$ & 0.737 & 2.488 & 0.115 & 2.090 \\
\hline $\begin{array}{l}\text { Seizure of } \\
\text { unknown } \\
\text { aetiology }\end{array}$ & 1.380 & 3.429 & 0.064 & 0.252 \\
\hline
\end{tabular}

LOS: length of stay; Wald: Wald test; OR: Odds Ratio; ICU: intensive care unit.

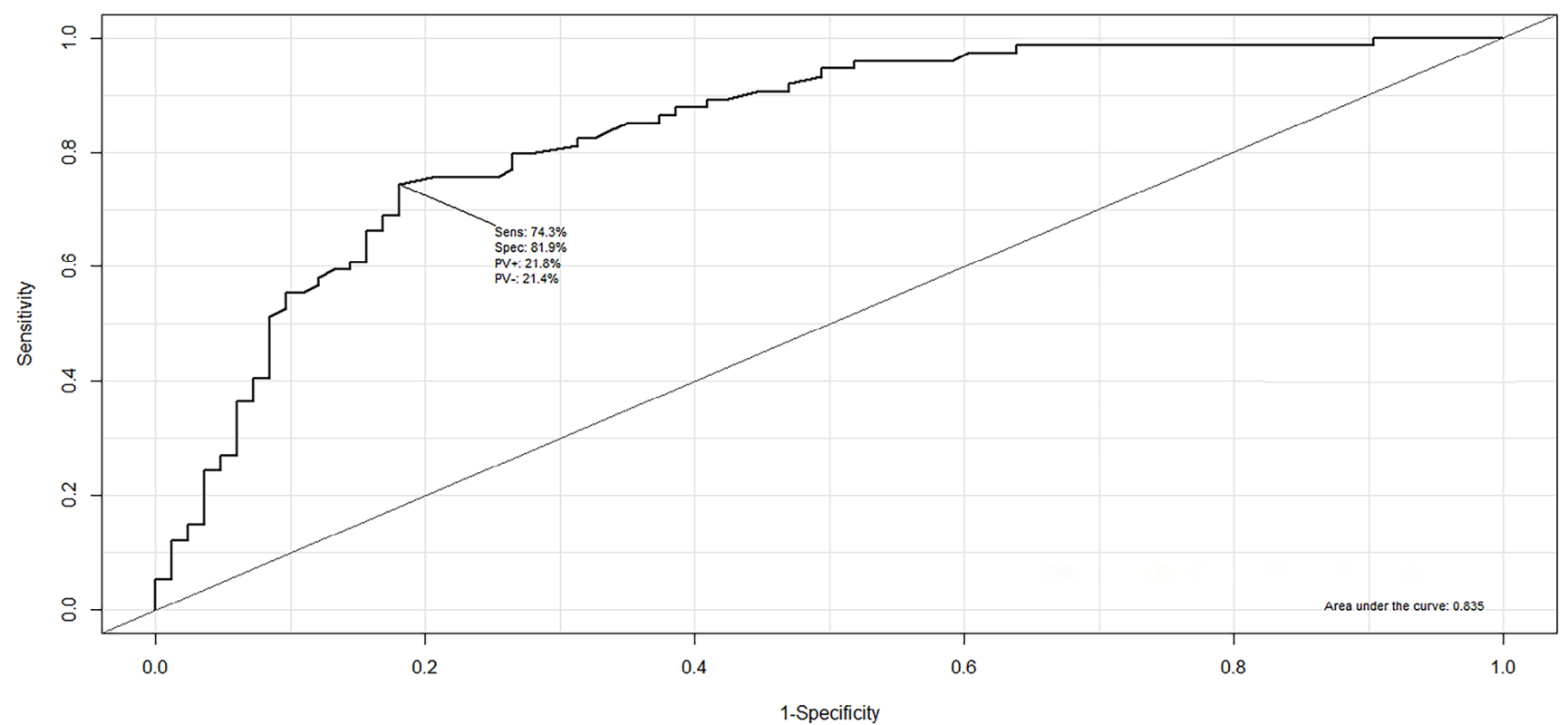

ROC curve: receiver operating characteristic curve; AUC: area under the curve; Sens: sensitivity; Spec: specificity; PV+: positive predictive value; PV-: negative predictive value.

Figure 1. ROC curve from the multivariate model of predictors of long length of hospital stay among 158 elders admitted with seizures in a tertiary centre. 


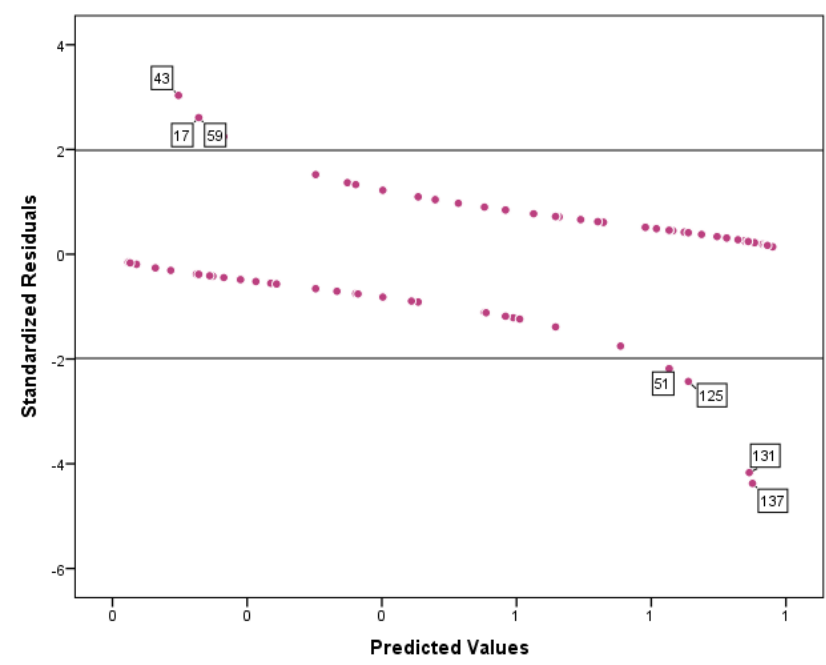

Numbers inside the squares represent outliers.

Figure 2. Residual analysis plot for detecting influential cases from the analysis of predictors of long length of hospital stay among elders admitted with seizures in a tertiary centre.

exclusions did not improve the significance or the quality of the adjusted logistic model.

\section{DISCUSSION}

Long LOS is common among elderly inpatients and it is one of the most important undesirable outcomes in that it is associated with hospital mortality and higher healthcare costs $^{6}$. In this study, we employed a comprehensive method of patient enrolment as we selected not only patients who were admitted with seizures but also patients who experienced seizures during hospitalization; in addition, it was a prospective collection. We studied a population of 159 elderly inpatients with a high mean age $(25 \%$ of patients were 85 years old or older). These patients had a median of five comorbidities, with a range of 4 to 7 chronic diseases; patient multimorbidity is indeed quite common among elderly inpatients ${ }^{9}$. We found a great number of variables associated with long LOS, not only in demographic data but also among the most frequent neurological disorders, comorbidities, and seizure disorders (Tables 1,2, and 3). However, in the final model, we identified only five important variables (ICU admission, movement disorder, urinary tract infection, sepsis, and early seizure recurrence) as strong independent risk factors for long LOS and three variables associated with a low chance of long LOS (female sex, hypothyroidism, and seizure of unknown aetiology). ICU admission was very common in our cohort, occurring in 97 (61\%) patients. Seizures in ICU patients may result from neurological disorders, clinical disorders, side effects of medication, and drug abstinence; patients can present with several clinical features, such as subtle twitching, convulsive seizures, or, more frequently, convulsive SE or non-convulsive SE, which are associated with high mortality ${ }^{27}$. Additionally, cases of stroke and seizures usually demand a longer LOS when compared to other ICU patients ${ }^{28}$. The present study population included some cases of convulsive and non-convulsive SE, which is usually an underdiagnosed condition and it is associated with longer length of stay ${ }^{12,29}$. In this study, both clinical types of SE were related to long LOS according to study criteria; however, after multivariate analysis, SE was not a statistically significant predictor of long LOS. Both urinary tract infection and sepsis were identified as strong predictors of long LOS and they were quite common complications among our study patients, with urinary tract infections occurring in 45 (28\%) and sepsis in $26(16 \%)$ patients. In a retrospective study of 366 ICU records, the authors found urinary tract infection was the second most common infection (with pneumonia being the most common) and patients with infections had a longer LOS (with a median of 16 days) than other patients $^{30}$. Sepsis is a severe complication of infection, especially in elderly inpatients, and it is usually associated with high mortality and long LOS ${ }^{31}$. Both urinary tract infection and sepsis are complications that can be prevented, e.g. by avoiding inappropriate use of urinary catheters and improving protocols for early recognition and management of infection $^{32,33}$. Movement disorder was another variable identified in this study as a predictor of long LOS, even though we had only 14 (9\%) patients with this condition. Parkinson's disease, chorea, progressive supranuclear palsy, Huntington's disease, corticobasal degeneration, and other movement disorders have been reported to be related to seizures; in addition, focal dyskinesia and other involuntary movements are frequently associated with seizures in case reports of anti-NMDA receptor encephalitis ${ }^{34,35,36,37,38}$. Parkinson's disease is the most common movement disorder, a complex disorder with motor and non-motor symptoms, which also negatively affects LOS; to avoid long LOS, it should hence be managed by specialists ${ }^{39}$. Early seizure recurrence was an important outcome found in $44(28 \%)$ patients in our population. The present study showed early recurrence of seizure was a strong predictor of long LOS. This condition was the subject of a recent study investigating potential predictors, which identified psychiatric disorder, sepsis, and cardiac arrhythmia as predictors of early seizure recurrence and also found an association of early recurrence of seizure with long $\mathrm{LOS}^{7}$. It might thus be reasonable to regard patients with any of these conditions as patients with epilepsy and to treat them just after the first seizure to avoid recurrence and possibly long LOS.

One of the limitations of this study was that we included a relatively small sample of a heterogeneous population of elderly patients from a single centre, narrowing its scope to a more exploratory approach. However, long LOS was a common occurrence among elderly patients who were admitted with seizures or who experienced seizures throughout hospitalization. The identification of predictors of long LOS among 
inpatients with seizures is a matter of interest in that we can avoid its consequences, such as increased morbidity and mortality, and higher healthcare costs ${ }^{4}$. Although hospital mortality was not a subject discussed in this study, it is worth mentioning that the case fatality rate in the study population was $9 \%$, which was quite high.

In conclusion, long LOS is a major undesirable outcome and it was common among the elderly patients who were admitted with seizures or experienced seizures during hospitalization in our study. We found ICU admission, urinary tract infection, movement disorder, early seizure recurrence, and sepsis to be independent predictors of long LOS, some of which are potentially preventable risk factors; these findings should be confirmed with further studies.

\section{ACKNOWLEDGEMENT}

We are grateful to Lucas E. Oliveira for his valuable contribution to the statistical analysis of this study.

\section{References}

1. United Nations Programme on Aging. Peace, dignity and equality on a healthy planet. Shaping our future together: aging; 2019. Available from: https://www.un.org/en/sections/issues-depth/ageing/.

2. Brasil. Instituto Brasileiro de Geografia e Estatística. Numero de idosos cresce 18\% em cinco anos e ultrapassa 30 milhões em 2017. Available from: https://agenciadenoticias.ibge.gov.br/agencia-noticias/2012agencia-de-noticias/noticias/20980-numero-de-idosos-cresce.

3. Jacob L, Bohlken J, Schmitz B, Kostev K. Incidence of epilepsy and associated factors in elderly patients in Germany. Epilepsy Behav. 2019 Jan;90:107-11. https://doi.org/10.1016/j.yebeh.2018.10.035

4. Mendizabal A, Thibault DP, Willis AW. Patient safety events in hospital care of individuals with epilepsy. Epilepsia. 2016 Aug;57(8):1301-9. https://doi.org/10.1111/epi.13440

5. Kortland LM, Alfter A, Bähr O, Carl B, Dodel R, Freiman TM, et al. Costs and cost-driving factors for acute treatment of adults with status epilepticus: A multicenter cohort study from Germany. Epilepsia. 2016 Dec;57(12):2056-66. https://doi.org/10.1111/epi.13584

6. Ishak KJ, Stolar M, Hu MY, Alvarez P, Wang Y, Getsios D, et al. Accounting for the relationship between per diem cost and LOS when estimating hospitalization costs. BMC Health Serv Res. 2012 Dec;12:439. https://doi.org/10.1186/1472-6963-12-439

7. Assis T, Bacellar A, Costa G, Pires E, Nascimento O. Predictors of early seizure recurrence among elderly inpatients admitted to a tertiary center: A prospective cohort study. Epilepsy Behav. 2019 Sep;98(Pt A):145-52. https://doi.org/10.1016/j.yebeh.2019.07.004

8. Corbi G, Gambassi G, Pagano G, Russomanno G, Conti V, Rengo G, et al. Impact of an Innovative educational strategy on medication appropriate use and length of stay in elderly patients. Medicine (Baltimore). 2015 Jun;94(24):e918. https://doi.org/10.1097/ MD.0000000000000918

9. Bacellar A, Pedreira BB, Costa G, Assis T. Frequency, associated features, and burden of neurological disorders in older adult inpatients in Brazil: a retrospective cross-sectional study. BMC Health Serv Res. 2017 Jul;17:504.https://doi.org/10.1186/s12913-017-2260-x

10. Bacellar A, Pedreira BB, Costa G, Assis T, Lobo C, Nascimento O. Predictors of readmission and long length of stay in elders admitted with neurological disorders in a tertiary center: a real-world investigation. Arq Neuro-Psiquiatr. 2019;77(5):321-9. https://doi. org/10.1590/0004-282×20190041

11. Freitas-Lima P, Baldoni Ade O, Alexandre V, Pereira LR, Sakamoto AC Drug utilization profile in adult patients with refractory epilepsy at a tertiary referral center. Arq Neuro-Psiquiatr. 2013;71(11):856-61. https://doi.org/10.1590/0004-282X20130169

12. Stelzer FG, Bustamante GO, Sander H, Sakamoto AC, Fernandes RM. Short-term mortality and prognostic factors related to status epilepticus. Arq Neuro-Psiquiatr. 2015;73(8):670-5. https://doi. org/10.1590/0004-282X20150082
13. Bacellar A, Assis T, Pedreira BB, Costa G, Nascimento OJM. Hospital mortality among elderly patients admitted with neurological disorders was not predicted by any particular diagnosis in a tertiary medical center. Open Neurol J. 2018 Jan;12:1-11. https://doi. org/10.2174/1874205X01812010001

14. Assis TR, Bacellar A, Costa G, Nascimento OJ. Etiological prevalence of epilepsy and epileptic seizures in hospitalized elderly in a Brazilian tertiary center - Salvador - Brazil. Arq Neuro-Psiquiatr. 2015 Feb;73(2):83-9. https://doi.org/10.1590/0004-282X20140217

15. Assis TM, Bacellar A, Costa G, Nascimento OJ. Mortality predictors of epilepsy and epileptic seizures among hospitalized elderly. Arq Neuro-Psiquiatr. 2015 Jun;73(6):510-5. https://doi. org/10.1590/0004-282X20150043

16. Assis TR, Nascimento OJ, Costa G, Bacellar A. Antiepileptic drugs patterns in elderly inpatients in a Brazilian tertiary center, Salvador, Brazil. Arq Neuro-Psiquiatr. 2014;72(11):874-80. https://doi. org/10.1590/0004-282X20140151

17. van Drimmelen-Krabbe JJ, Bradley WG, Orgogozo JM, Sartorius N. The application of the International Statistical Classification of Diseases to neurology: ICD-10 NA. J Neurol Sci. 1998 Nov;161(1):2-9. https://doi.org/10.1016/s0022-510x(98)00217-2

18. Hugo J, Ganguli M. Dementia and cognitive impairment: epidemiology, diagnosis, and treatment. Clin Geriatr Med. 2014 UG;30(3):421-42. https://doi.org/10.1016/j.cger.2014.04.001

19. Meagher DJ, Morandi A, Inouye SK, Ely W, Adamis D, Maclullich AJ, et al. Concordance between DSM-IV and DSM-5 criteria for delirium diagnosis in a pooled database of 768 prospectively evaluated patients using the delirium rating scale-revised-98. BMC Med. 2014;12:164. https://doi.org/10.1186/s12916-014-0164-8

20. Scheffer IE, Berkovic S, Capovilla G, Connolly MB, French J, Guilhoto $L$, et al. ILAE classification of the epilepsies: Position paper of the ILAE Commission for Classification and Terminology. Epilepsia. 2017 Apr;58(4):512-21. https://doi.org/10.1111/epi.13709

21. Fisher RS, Cross JH, French JA, Higurashi N, Hirsch E, Jansen FE, et al. Operational classification of seizure types by the International League Against Epilepsy: Position Paper of the ILAE Commission for Classification and Terminology. Epilepsia. 2017 Apr;58(4):522-30. https://doi.org/10.1111/epi.13670

22. Beghi E, Carpio A, Forsgren L, Hesdorffer DC, Malmgren K, Sander JW, et al. Recommendation for a definition of acute symptomatic seizure. Epilepsia. 2010 Apr;51(4):671-5. https://doi.org/10.1111/ j.1528-1167.2009.02285.x

23. Phabphal K, Geater A, Limapichat K, Sathirapanya P, Setthawatcharawanich S. Risk factors of recurrent seizure, co-morbidities, and mortality in new onset seizure in elderly. Seizure. 2013 Sep;22(7):577-80. https://doi.org/10.1016/j. seizure.2013.04.009 
24. Trinka E, Cock H, Hesdorffer D, Rossetti AO, Scheffer IE, Shinnar S, et al. A definition and classification of status epilepticus--Report of the ILAE Task Force on Classification of Status Epilepticus. Epilepsia. 2015 Oct;56(10):1515-23. https://doi.org/10.1111/epi.13121

25. Fisher RS, Acevedo C, Arzimanoglou A, Bogacz A, Cross JH, Elger CE, et al. ILAE official report: a practical clinical definition of epilepsy. Epilepsia. 2014 Apr;55(4):475-82. https://doi.org/10.1111/epi.12550

26. Prados-Torres A, Calderon-Larranaga A, Hancco-Saavedra J, Poblador-Plou B, van den Akker M. Multimorbidity patterns: a systematic review. J Clin Epidemiol. 2014 Mar;67(3):254-66. https:// doi.org/10.1016/j.jclinepi.2013.09.021

27. Ch'ang J, Claassen J. Seizures in the critically ill. Handb Clin Neurol. 2017;141:507-29. https://doi.org/10.1016/B978-0-444-63599$0.00028-4$

28. Siraklow S, Trongtrakul K, Chittawatanarat K, Pathonsamit C, Teeratchanan T, Poopipatpab S. The incidence, characteristics, and outcomes of stroke and seizure in critically ill surgical patients: a multicenter cohort study of Thai Surgical Intensive Care Units (THAISICU Study). J Med Assoc Thai. 2016;99 Suppl 6:S233-S41.

29. Rudin D, Grize L, Schindler C, Marsch S, Ruegg S, Sutter R. High prevalence of nonconvulsive and subtle status epilepticus in an ICU of a tertiary care center: a three-year observational cohort study. Epilepsy Res. 2011 Sep;96(1-2):140-50. https://doi.org/10.1016/j. eplepsyres.2011.05.018

30. Pradhan NP, Bhat SM, Ghadage DP. Nosocomial infections in the medical ICU: a retrospective study highlighting their prevalence, microbiological profile and impact on ICU stay and mortality. J Assoc Physicians India. 2014 Oct;62(10):18-21.

31. Westphal GA, Pereira AB, Fachin SM, Barreto ACC, Bornschein A, Caldeira Filho M, et al. Characteristics and outcomes of patients with community-acquired and hospital-acquired sepsis. Rev Bras Ter
Intensiva. 2019 Jan/Mar;31(1):71-8. https://doi.org/10.5935/0103$507 \times .20190013$

32. Hu FW, Yang DC, Huang CC, Chen $\mathrm{CH}$, Chang CM. Inappropriate use of urinary catheters among hospitalized elderly patients: Clinician awareness is key. Geriatr Gerontol Int. 2015 Dec;15(12):1235-41. https://doi.org/10.1111/ggi.12431

33. De Groot B, Struyk B, Najafi R, Halma N, Pelser L, Vorst D, et al. Inclusion of emergency department patients in early stages of sepsis in a quality improvement programme has the potential to improve survival: a prospective dual-centre study. Emerg Med J. 2017 Sep;34(9):578-85. https://doi.org/10.1136/emermed-2015-205645

34. Gruntz K, Bloechliger M, Becker C, Jick SS, Fuhr P, Meier CR, et al. Parkinson disease and the risk of epileptic seizures. Ann Neurol. 2018 Feb;83(2):363-74. https://doi.org/10.1002/ana.25157

35. Sipila JO, Soilu-Hanninen M, Majamaa K. Comorbid epilepsy in Finnish patients with adult-onset Huntington's disease. BMC Neurol. 2016 Feb;16:24. https://doi.org/10.1186/s12883-016-0545-z

36. Douglas VC, DeArmond SJ, Aminoff MJ, Miller BL, Rabinovici GD. Seizures in corticobasal degeneration: a case report. Neurocase. 2009 Aug;15(4):352-6. https://doi.org/10.1080/13554790902971158

37. Nygaard TG, Duvoisin RC, Manocha M, Chokroverty S. Seizures in progressive supranuclear palsy. Neurology. 1989 Jan;39(1):138-40. https://doi.org/10.1212/wnl.39.1.138

38. Freri E, Matricardi S, Patrini M, Binelli S, Andreetta F, Teutonico F, et al. Focal seizure, focal dyskinesia, or both? A complex motor phenomenon reveals anti-NMDAR encephalitis. Seizure. 2015 Apr;27:16-8. https://doi.org/10.1016/j.seizure.2015.02.005

39. Skelly R, Brown L, Fakis A, Kimber L, Downes C, Lindop F, et al. Does a specialist unit improve outcomes for hospitalized patients with Parkinson's disease? P Parkinsonism Relat Disord. 2014 Nov;20(11):1242-7. https://doi.org/10.1016/j.parkreldis.2014.09.015 